\title{
Time-Based Process Mapping for Lead Time Compression in the Apparel Supply Chain: A Case Study
}

\author{
Chowdhury Jony Moin \\ Department of Industrial and Production Engineering, \\ Shahjalal University of Science and Technology, \\ University Ave, Sylhet 3114, Bangladesh; \\ Department of Textile Engineering, \\ Ahsanullah University of Science and Technology, \\ $141 \& 142$, Love Road, Dhaka 1208, Bangladesh. \\ Mohammad Iqbal \\ Department of Industrial and Production Engineering, \\ Shahjalal University of Science and Technology, \\ University Ave, Sylhet 3114, Bangladesh. \\ A. B. M. Abdul Malek \\ Department of Industrial and Production Engineering, \\ Shahjalal University of Science and Technology, \\ University Ave, Sylhet 3114, Bangladesh.

\section{Rezwanul Haque} \\ School of Science and Engineering, \\ University of the Sunshine Coast, \\ 90 Sippy Downs Drive, Sippy Downs, QLD 4556, Australia. \\ Corresponding author: rhaque@usc.edu.au
}

(Received May 17, 2019; Accepted August 30, 2019)

\begin{abstract}
Fashion industries are highly globalized as designing, manufacturing and selling are performed in different countries. As a result, it has a long supply chain and long lead time. Identification of value-added time through-out the supply chain is a key research area in apparel industries. This case study investigated detailed activities of thirty contracts of an apparel supply chain by considering the manufacturer as a coupling point of upstream (suppliers) and downstream (buyer). The contract frequencies were analyzed based on lead time and quantity. Each contract was analyzed using a time-based process mapping (TBPM). TBPMs of all contracts showed that overall $45 \%$ were non-value-added activities throughout the chain. It was also identified that the non-value activities were independent of the contract volume. This study recommends time compression methodology to reduce the non-value-added activities by using advanced manufacturing technologies. The methodology and recommended time compression ways of this study can be applied to other supply chains.
\end{abstract}

Keywords- Lead time, Supply chain management, Time to market, TBPM.

\section{Introduction}

The clothing sector is now requiring frequent and trendy product changes in stores, quick response to trendy product development according to customer preferences (Martínez et al., 2015). Contrary, these fashion industries are highly globalized as its operations throughout the supply chain from design to manufacturing, and finally, selling are performed in different countries (Čiarnienè and 
International Journal of Mathematical, Engineering and Management Sciences

Vol. 5, No. 1, 96-107, 2020

https://doi.org/10.33889/IJMEMS.2020.5.1.009

Vienažindienė, 2014). Thus, it has a long supply chain and long lead time. Consequently, this long lead time deals with longer forecast horizon and any longer horizon worsen the forecast (Christopher and Towill, 2002). Whereas, Fashion markets typically show short life-cycles, high volatility, low predictability and high instinct purchasing (Christopher and Towill, 2002). Because of such characteristics, forecasting accuracy is extremely difficult. These market complexities, ferocious competition and fast changes in demand necessitate the companies to be ready to react promptly to customers' needs (Bhardwaj and Fairhurst, 2010). To do such, apparel manufacturer shifted to Mass-Customization from Mass Production (Moin et al., 2013). Mass customization can be described as manufactures ability to meet market demand with high product variety without substantial trade-offs in cost, delivery and quality (McCarthy, 2004). Mass customization strategies lead the manufacturers to supply an increasingly unsettled marketplace with customized products responding to individual customer requirements with minimal loss of production efficiency (Liu and Deitz, 2011). Two methodologies can be applied to implement Mass customization: i) Processes customization and ii) Advanced manufacturing technologies which include communication and network (Da Silveira et al., 2001).

Customers do not care much about how a company gets the order and deliveries of a product (Moin et al., 2018). To satisfy the customers there are three competitive dimensions, i.e. price, product differentiation and delivery time, which depends on the lead time (Magnusson and Simonsson, 2012). This lead time can be divided in many ways. In most common practice, lead-time typically includes two components: Information lead times (i.e., the time it takes to process an order) and Order lead times (i.e., the time it takes to produce and ship the item). Nowadays, time became the most important factor in this competitive business environment. Several strategies are employed by different companies to reduce the lead time (Pine et al., 1993). For example, information lead time can be reduced by using very sophisticated and modern communication system while Order lead time can be reduced through efficient supply chain management (Simchi-Levi et al., 2008). Different time compression strategies, their goals and effects on lead time based on the age of the business are summarized in Table 1.

One of the effective ways to reduce the lead time is Time-based study. The term time-based study first appeared in the open literature in 1988 (Stalk, 1988). Time-based competition is a strategy by which a firm makes better use of time as a resource to acquire a competitive advantage. It seeks to compress the time required to Propose, Develop, Manufacture, Market and Deliver its products (Qunhui and Yang, 2011). To get such time-based advantages it is necessary to shorten the lead time as much as possible. There are two measures prior to implementing time-based strategies- i) Timeliness-to-market (this includes Fast-to-market, Fast-to-produce and Early withdraw the product from the market) and ii) Measure of ' $\mathrm{P}$ time' and ' $\mathrm{D}$ time'. $\mathrm{P}$ time measures the time needed for all the necessary processes and delivers that product to the customer (generally known as Lead time). D time measures the time for which a customer is willing to wait to have their demand fulfilled (Harrison and Hoek, 2011).

For managing timeliness or reducing the gap between $\mathrm{P}$ time and $\mathrm{D}$ time in the logistics pipeline several strategies are in practiced like make to order (MTO) and assemble to order (ATO) which consider a customer order decoupling point (CODP). MTO is a branch of Lean Manufacturing philosophy where manufacturing starts only after receiving the customer's order (Kabaivanova, 2015). This is a Pull type production system an oppose to a Push type production system like Make to Stock (MTS). ATO is a similar pull-type production system where assembly starts only after a demand is created (Song and Zipkin, 2003). A Time-Based Process Map (TBPM) identifies the 
International Journal of Mathematical, Engineering and Management Sciences

Vol. 5, No. 1, 96-107, 2020

https://doi.org/10.33889/IJMEMS.2020.5.1.009

value-adding and non-value adding activities on a supply chain and guides the user for generating short term and long-term solution (Harrison and Hoek, 2011). A methodical framework for implementation of Time-based strategies is shown in Figure 1.

Table 1. Lead time reduction strategies depending on their age (Simchi-Levi et al., 2008)

\begin{tabular}{|c|c|c|c|c|c|}
\hline Age of Business & Time Compression strategies & $\begin{array}{l}\text { The goal of Time } \\
\text { Compression } \\
\text { strategies }\end{array}$ & $\begin{array}{l}\text { Lead } \\
\text { time }\end{array}$ & $\begin{array}{c}\text { Customer } \\
\text { satisfaction }\end{array}$ & Remarks \\
\hline $\begin{array}{l}\text { Age of } \\
\text { manufacturing } \\
(1900-1960)\end{array}$ & $\begin{array}{l}\text { Setup redesign, Inventory control, } \\
\text { Cellular manufacturing, Preventive } \\
\text { maintenance, Employee involvement in } \\
\text { problem-solving, MRP, MRP II, etc. }\end{array}$ & $\begin{array}{c}\text { Reduce production } \\
\text { time }\end{array}$ & Long & Low & $\begin{array}{c}\text { Reduce } \\
\text { production time }\end{array}$ \\
\hline $\begin{array}{c}\text { Age of } \\
\text { distribution } \\
(1960-1990)\end{array}$ & $\begin{array}{c}\text { All above + Direct shipment, } \\
\text { Warehousing, Cross-docking, } \\
\text { Transshipment, Product differentiation, } \\
\text { Push-pull boundary, etc. }\end{array}$ & $\begin{array}{l}\text { Manufacturing age } \\
\text { plus } \\
\text { Reduce replenish time }\end{array}$ & Medium & Average & $\begin{array}{l}\text { Reduce } \\
\text { production and } \\
\text { distribution time }\end{array}$ \\
\hline $\begin{array}{l}\text { Age of } \\
\text { information } \\
(1990-2010)\end{array}$ & $\begin{array}{l}\text { All above + Concurrent and parallel } \\
\text { processing, Electronic Data Interchange, } \\
\text { Delayed product differentiation, Supplier } \\
\text { relationship, Vendor-managed inventory } \\
\text { (VMI), E-commerce, ERP, ERP II, etc. }\end{array}$ & $\begin{array}{l}\text { Manufacturing and } \\
\text { distribution age plus } \\
\text { Reduce ordering time }\end{array}$ & Medium & $\begin{array}{l}\text { Above } \\
\text { average }\end{array}$ & $\begin{array}{l}\text { Reduce } \\
\text { information \& } \\
\text { material flow } \\
\text { time. }\end{array}$ \\
\hline $\begin{array}{l}\text { Age of the } \\
\text { customer } \\
(2010 \text {-next) }\end{array}$ & $\begin{array}{l}\text { All above + Customer Relationship } \\
\text { Management, Customer-focused } \\
\text { strategy, Demand forecasting from } \\
\text { customer behavior, involving the } \\
\text { customer in new products development, } \\
\text { shortening business life cycle and } \\
\text { Introduce customer-centric business, etc. }\end{array}$ & $\begin{array}{l}\text { Manufacturing, } \\
\text { distribution and } \\
\text { information age plus } \\
\text { Reduce demand } \\
\text { forecasting time }\end{array}$ & Short & High & $\begin{array}{l}\text { Satisfy \& } \\
\text { Surprise the } \\
\text { customers }\end{array}$ \\
\hline $\begin{array}{l}\text { Age of market- } \\
\text { on-time } \\
\text { (Authors' } \\
\text { perception }\end{array}$ & $\begin{array}{l}\text { All above + Demand rise \& creation, } \\
\text { manufacturing as per demand and } \\
\text { fulfillment of the demand. }\end{array}$ & $\begin{array}{l}\text { All of the above plus } \\
\text { Dominate market like } \\
\text { fashion leader and } \\
\text { Push sell with demand } \\
\text { rise and creation }\end{array}$ & $\begin{array}{l}\text { Very } \\
\text { short }\end{array}$ & Optimum & $\begin{array}{c}\text { Satisfy \& } \\
\text { Surprise the } \\
\text { customers and } \\
\text { control market }\end{array}$ \\
\hline
\end{tabular}

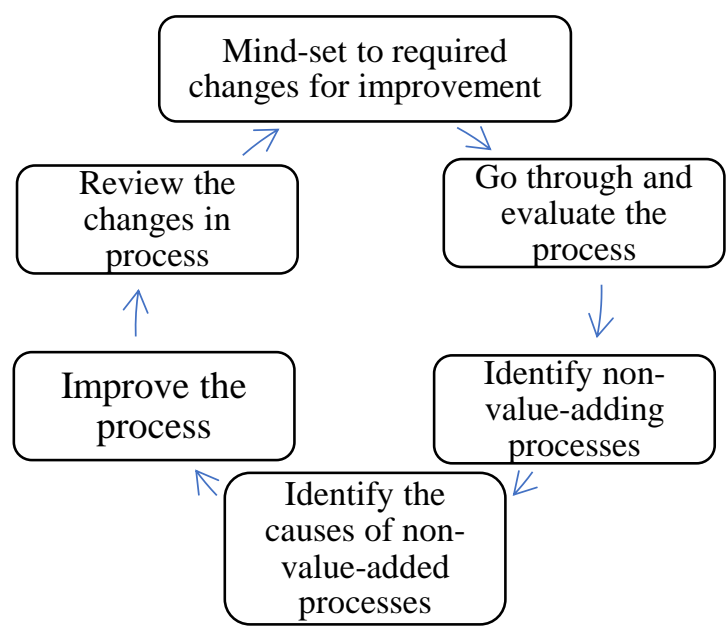

Figure 1. Methodology for time-based process improvement (Harrison and Hoek 2011) 
International Journal of Mathematical, Engineering and Management Sciences

Vol. 5, No. 1, 96-107, 2020

https://doi.org/10.33889/IJMEMS.2020.5.1.009

Every process mapping including TBPM demonstrates the information flows and the physical flows together (Bicheno and Holweg, 2000). TBPM is one of the seven mapping tools of 'Seven Value Stream Mapping Tools' (Gracanin et al., 2014). 'Seven Value Stream Mapping Tools' includes: (i) Process activity mapping, (ii) Supply chain response matrix, (iii) Production variety funnel, (iv) Quality filter mapping, (v) Demand amplification mapping, (vi) Decision point analysis and (vii) Physical structure mapping such as Value stream costing, Cost-time and TBPM (Chapman, 2003). For the application of Physical structure mapping, cost and quality cannot be measured properly due to the poor understanding of costs and quality in reality (Harrison and Hoek, 2011). Whereas time can be measured easily and that everyone understands, even people with minimal training can measure the performance of processes or activities of any large issues in terms of time. Hence TBPM fits well to all kind of process more than a cross-functional toolbox of Seven Value Stream Mapping Tools. The application of TBPM was used to a range of industrial sectors including aerospace and construction, textile supply chain and automotive industries to decrease the lead time in production (Forza and Filippini, 1993).

Generally, all participants of a supply chain (manufacturers, suppliers, buyer and retailers) have their own and individual core competencies. When all the partners merge and conjunct their individual competencies, they can achieve their goals. The time-based strategy for Quick Response also becomes a great premium for both the organization and supply chain level. To achieve timebased competitive advantages, this case study adopts time-based process mapping (TBPM), an effective tool to create the visibility of value-adding and non-value adding time across the network.

\section{The Supply Chain under Investigation}

This case study focused on an apparel supply chain, of which upstream, downstream and manufacturer are located in different countries. The manufacturer is performing as a coupling point of upstream (Suppliers) and downstream (Buyers). In this supply chain, the buyer has direct linkages with consumers through his own retail outlet. Hence the buyer develops the forecasted styles through a manufacturer and manufacturer produces those styles by collecting required materials from suppliers. After developing a style, a corresponding contract is placed by the buyer to the manufacturer and the contract is executed through all supply chain participants. The chain structure is shown in Figure 2. It should be noted that no MTO or ATO strategy is applied currently on this supply chain. However, the authors of this manuscript offered an improved supply chain in the recommendation section.

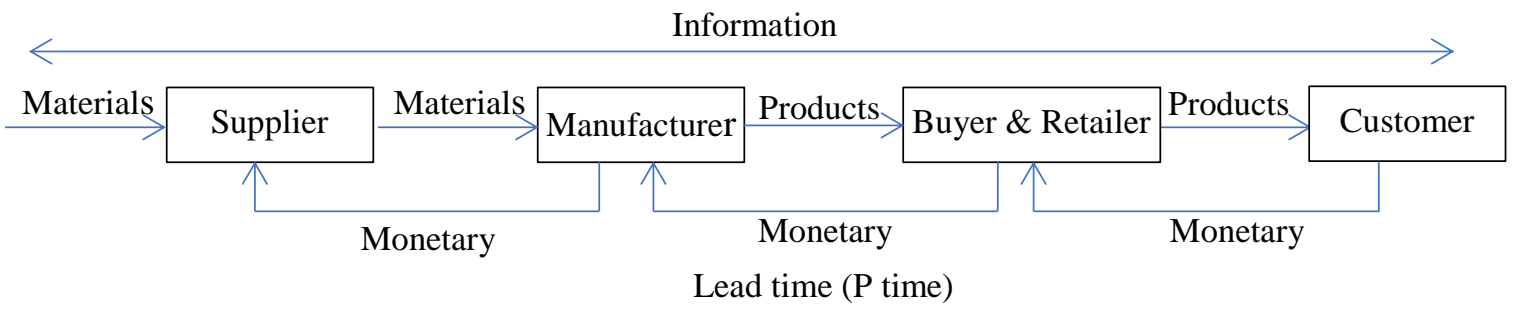

Figure 2. Supply chain structure of the current case study 
International Journal of Mathematical, Engineering and Management Sciences

Vol. 5, No. 1, 96-107, 2020

https://doi.org/10.33889/IJMEMS.2020.5.1.009

\section{Methodology}

Thirty contracts for the year 2017 of an apparel supply chain was collected. The activities for forecasting and product development were excused due to business confidentiality. Data on those contracts having different quantity for different product styles and different lead time were collected (Table 2). All contracts were categorized according to quantity and number of days in lead time. In addition to that, each contract was also analyzed through Time Based Process Mapping (TBPM).

Table 2. Lead times of 30 contracts of the case study

\begin{tabular}{|c|c|c|c|c|c|c|c|}
\hline Serial no. & Lead time & Serial no. & Lead time & Serial no. & Lead time & Serial no. & Lead time \\
\hline 1 & 171 & 9 & 155 & 17 & 148 & 25 & 135 \\
\hline 2 & 148 & 10 & 153 & 18 & 147 & 26 & 165 \\
\hline 3 & 149 & 11 & 152 & 19 & 136 & 27 & 148 \\
\hline 4 & 147 & 12 & 178 & 20 & 151 & 28 & 156 \\
\hline 5 & 160 & 13 & 179 & 21 & 179 & 29 & 143 \\
\hline 6 & 151 & 14 & 162 & 22 & 135 & 30 & 139 \\
\hline 7 & 171 & 15 & 179 & 23 & 149 & & \\
\hline 8 & 165 & 16 & 133 & 24 & 174 & & \\
\hline
\end{tabular}

By doing so, the non-value-added items were identified in the supply chain and the lead time was reduced by eliminating the non-value-added items. For example, a TBPM of a contract (no. 19 in Table 2) is shown in Figure 3. Thirty-seven activities were identified through TBPM and divided into five phases. Due to business confidentiality style no., activity start date and end date are not shown in Figure 3.

\section{Data Analysis}

The example shows that the TBPM for contract 1xxxxxx shows that total lead time for the contract was 136 days and among those 85 days for value-added and 51 days were non-value added. To identify value-added activities, the value gaining activities by supply chain participants were considered rather than the value-added to products. As for example, transportation activities are not adding any value to products but when products transport to profitable market helps the supply chain to gain more profits. So, only delayed or waiting were considered as non-value-added activities. Some value-added concurrent activities were also found but for those activities, time was calculated once. Phase wise value-added (VA) and non-value-added (NVA) activity days were calculated from the TBPM of each contract and tabulated in Table 3.

\subsection{Contract Variation}

The quantity of the selected contracts ranges from 2251 to 25264 pieces and those are divided into five groups according to quantity. The following Figure 4 shows the contract frequencies in each group and found that contract frequencies are more for a smaller quantity. The lead time of those contracts spans from 133 to 179 days with an average of 155.23 days and divided into five groups also. Among the contracts, $60 \%$ had lead time less than the average of lead time and $40 \%$ above the said. This is also a similar phenomenon like the number of contracts, i.e. contract frequencies are more for shorter lead time. 
International Journal of Mathematical, Engineering and Management Sciences

Vol. 5, No. 1, 96-107, 2020

https://doi.org/10.33889/IJMEMS.2020.5.1.009

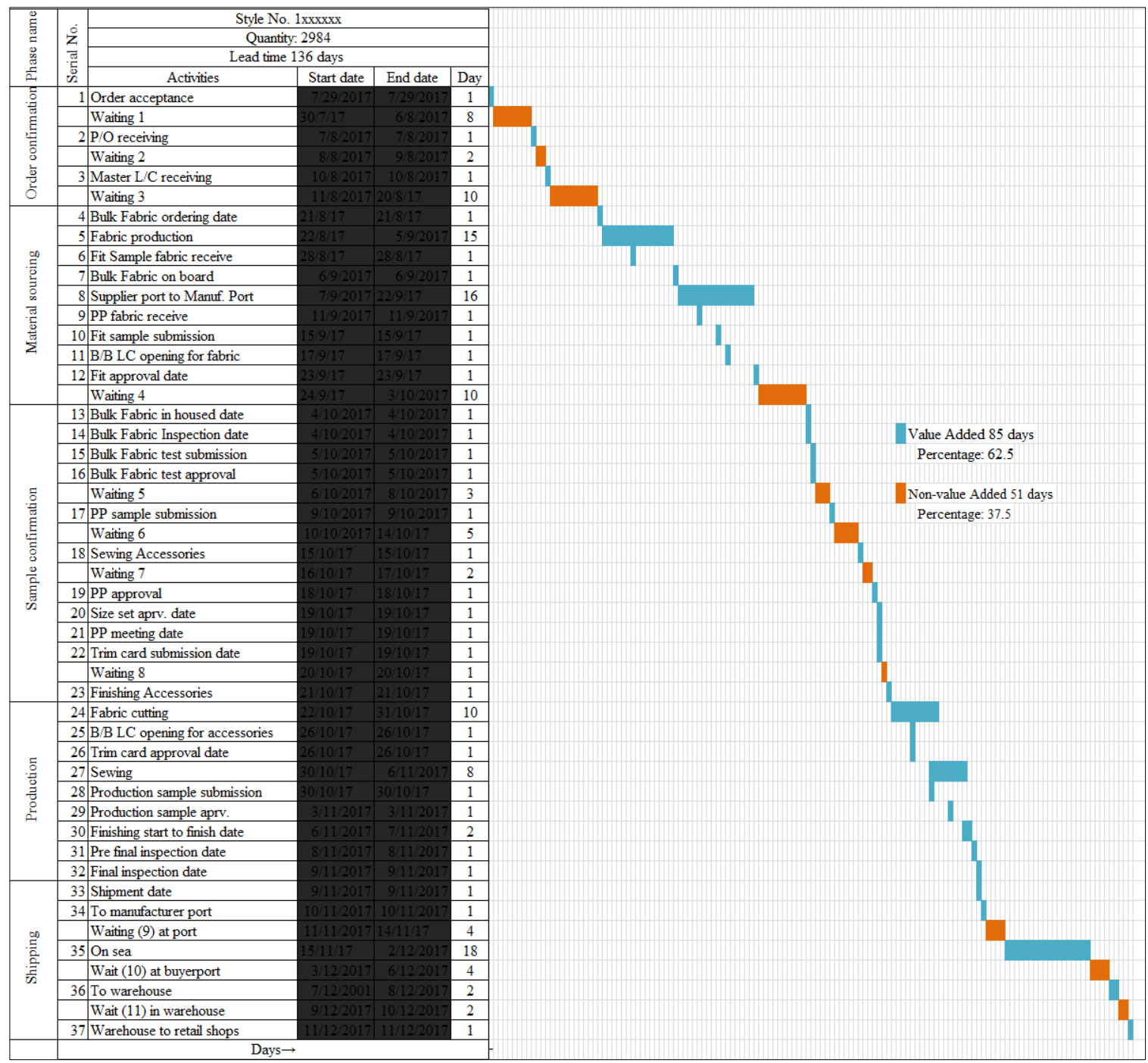

Figure 3. Time based process mapping (TBPM)

\subsection{TBPM}

Activity wise time-based process mappings for thirty contracts help to identify value-added (VA) and non-value-added (NVA) activities. The following Figure 5 shows the percentages of valueadded and non-value added activities against the contract variations: lead time and number of contracts as mentioned in section 4.1. 
International Journal of Mathematical, Engineering and Management Sciences

Vol. 5, No. 1, 96-107, 2020

https://doi.org/10.33889/IJMEMS.2020.5.1.009

Table 3. Phase wise value-added and non-value-added activity in days

\begin{tabular}{|c|c|c|c|c|c|c|c|c|c|c|c|}
\hline \multirow[t]{2}{*}{ 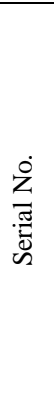 } & \multirow[t]{2}{*}{ 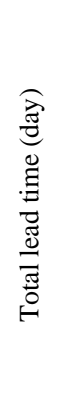 } & 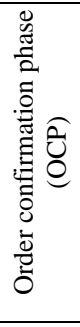 & $\begin{array}{l}\text { ठ } \\
. \Xi \\
.00 \\
: \Xi \\
: 0 \\
3 \\
3\end{array}$ & 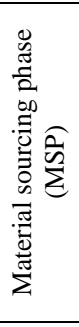 & 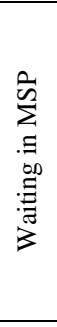 & 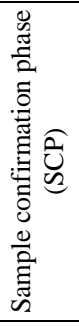 & 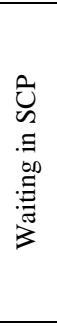 & 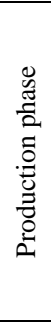 & 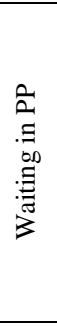 & 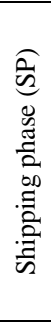 & 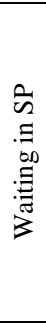 \\
\hline & & 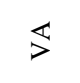 & 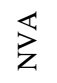 & 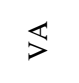 & 之 & 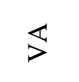 & 之 & 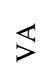 & 之 & 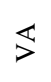 & 之 \\
\hline 1 & 171 & 3 & 25 & 38 & 16 & 9 & 6 & 16 & 25 & 23 & 10 \\
\hline 2 & 148 & 3 & 25 & 36 & 18 & 6 & 1 & 13 & 13 & 23 & 10 \\
\hline 3 & 149 & 3 & 18 & 37 & 13 & 9 & 10 & 12 & 14 & 23 & 10 \\
\hline 4 & 147 & 3 & 25 & 34 & 20 & 4 & 2 & 20 & 6 & 23 & 10 \\
\hline 5 & 160 & 3 & 18 & 32 & 18 & 6 & 7 & 24 & 19 & 23 & 10 \\
\hline 6 & 151 & 3 & 18 & 34 & 16 & 6 & 3 & 15 & 24 & 22 & 10 \\
\hline 7 & 171 & 3 & 18 & 38 & 29 & 6 & 18 & 23 & 3 & 23 & 10 \\
\hline 8 & 165 & 3 & 18 & 32 & 31 & 6 & 1 & 19 & 22 & 23 & 10 \\
\hline 9 & 155 & 3 & 25 & 38 & 16 & 4 & 0 & 11 & 25 & 23 & 10 \\
\hline 10 & 153 & 3 & 18 & 31 & 19 & 5 & 3 & 21 & 19 & 24 & 10 \\
\hline 11 & 152 & 3 & 25 & 35 & 19 & 6 & 8 & 22 & 2 & 22 & 10 \\
\hline 12 & 178 & 3 & 26 & 36 & 13 & 10 & 39 & 19 & 0 & 22 & 10 \\
\hline 13 & 179 & 3 & 26 & 46 & 49 & 2 & 4 & 12 & 6 & 22 & 9 \\
\hline 14 & 162 & 3 & 26 & 43 & 10 & 10 & 8 & 27 & 1 & 24 & 10 \\
\hline 15 & 179 & 3 & 13 & 35 & 19 & 11 & 36 & 22 & 7 & 23 & 10 \\
\hline 16 & 133 & 3 & 13 & 34 & 20 & 5 & 1 & 14 & 11 & 22 & 10 \\
\hline 17 & 148 & 3 & 21 & 33 & 13 & 7 & 17 & 17 & 4 & 23 & 10 \\
\hline 18 & 147 & 3 & 20 & 30 & 14 & 10 & 23 & 11 & 4 & 22 & 10 \\
\hline 19 & 136 & 3 & 20 & 34 & 10 & 7 & 11 & 19 & 0 & 22 & 10 \\
\hline 20 & 151 & 3 & 20 & 39 & 25 & 6 & 5 & 17 & 3 & 23 & 10 \\
\hline 21 & 179 & 3 & 13 & 31 & 23 & 10 & 49 & 16 & 2 & 23 & 9 \\
\hline 22 & 135 & 3 & 21 & 29 & 17 & 4 & 3 & 16 & 8 & 24 & 10 \\
\hline 23 & 149 & 3 & 21 & 32 & 22 & 5 & 2 & 30 & 1 & 23 & 10 \\
\hline 24 & 174 & 3 & 10 & 35 & 24 & 12 & 31 & 20 & 5 & 24 & 10 \\
\hline 25 & 134 & 3 & 10 & 36 & 29 & 3 & 0 & 16 & 4 & 23 & 10 \\
\hline 26 & 165 & 3 & 27 & 41 & 24 & 5 & 0 & 21 & 12 & 22 & 10 \\
\hline 27 & 148 & 3 & 24 & 39 & 18 & 6 & 6 & 17 & 3 & 22 & 10 \\
\hline 28 & 156 & 3 & 20 & 36 & 26 & 4 & 6 & 19 & 8 & 24 & 10 \\
\hline 29 & 143 & 3 & 20 & 33 & 21 & 6 & 2 & 16 & 10 & 22 & 10 \\
\hline 30 & 139 & 3 & 11 & 35 & 31 & 2 & 6 & 14 & 5 & 22 & 10 \\
\hline
\end{tabular}

From Figure 5, it is found that the average non-value-added activities of the process in the supply chain range from $42 \%$ to $49 \%$ for led time contract variation and $43 \%$ to $48 \%$ for product quantity contract variation. The average value-added time of 30 contracts is found $56 \%$ according to the lead time. The non-value added (NVA) and value-added (VA) activities of each category (lead time vs quantity) are very similar. So, it can be said that the length of lead time and quantity in each contact does not influence the non-value added and value-added activities percentages. 


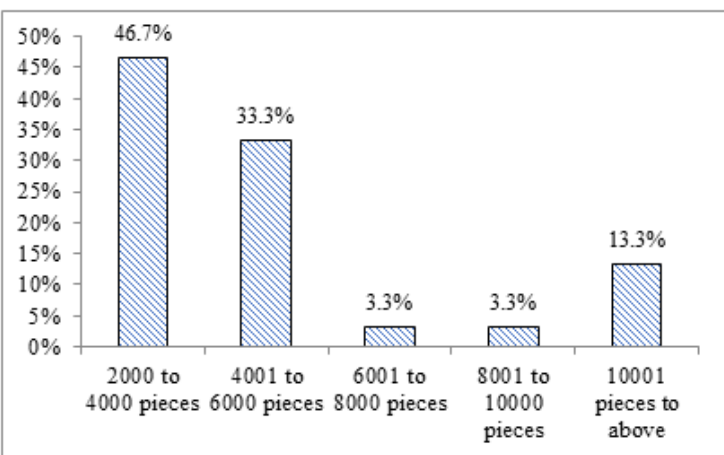

(a)

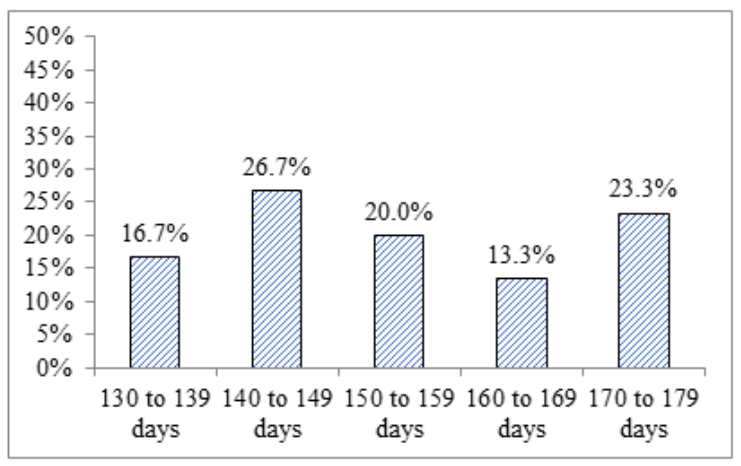

(b)

Figure 4. Variation on contracts depending on (a) quantity and (b) lead time

TBPM is usually done for individual products and activity-wise. To get the time compression scenario it was analyzed phase-wise. The average percentage of VA activities was also analyzed according to the 5 phases (Order confirmation, Materials sourcing, Sample confirmation, Production, and Shipping) shown in Figure 3. The average percentages of value-added and nonvalue-added times according to phases are shown in Figure 6 a.

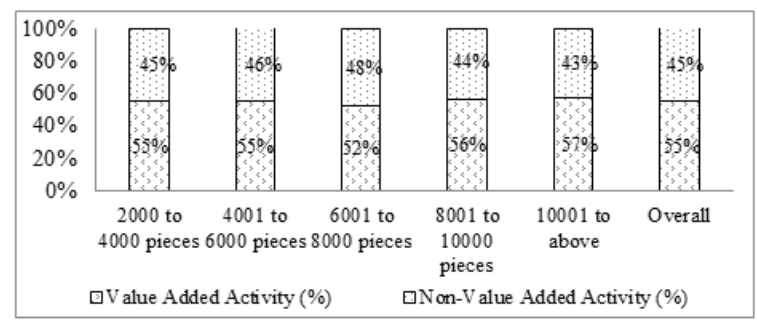

(a)

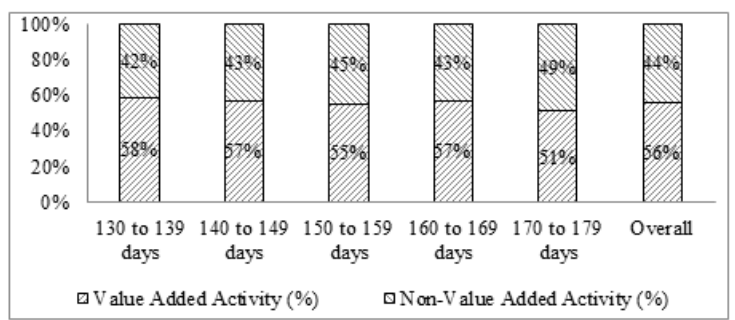

(b)

Figure 5. Non-value-added and value-added activities depending on (a) quantity and (b) lead time

Among the five phases, Order confirmation phase and Material sourcing phase have long waiting time and in both cases, it is $13 \%$ of the total lead time. It is found that overall of $44 \%$ of lead time was lost in non-value-added activities. The percentage of non-value activities against each phase was also studied and shown in Figure 6b. Around 60\% of the NVA happened during the order confirmation and material sourcing phase.

\section{Discussion and Recommendations}

In the first phase (order confirmation phase), monetary issues slower the process and TBPM in Figure 3 show that 20 days (around $15 \%$ of the total lead time) are non-value-added time. For all thirty contracts, NVA is $13 \%$ of the total lead time and $29 \%$ of the total non-value-added time (Figure 6). The second phase (material sourcing) is the longest period where 11 out of 37 activities took place. Major activities in this phase are fabric production and shipment of fabric to apparel manufacturer. Figure 3 shows that these major activities conceive 31 days (around $23 \%$ of the total 
International Journal of Mathematical, Engineering and Management Sciences

Vol. 5, No. 1, 96-107, 2020

https://doi.org/10.33889/IJMEMS.2020.5.1.009

lead time), other value-added activities conceive only 04 days and non-value-added activities conceive time 10 days. Sample confirmation phase is complicated to distinguish because of parallel activities within the phase and with other phases (predecessor and successor). Figure 3 shows that this is the shortest one and non-value-added time ( 11 days) is greater than the value-added time (07 days). For all thirty contracts, it is found similar as shown in Figure 6. For the apparel production phase, all the items were found to be value-added activities without having a waiting time (Figure 3). However, overall 6\% NVA was identified for this phase (Figure 6) when considering all the thirty contracts. Figure 3 also shows the last one is shipping phase where transportation to destination time is 22 days (around 16\% of the total lead time) and waiting time is 10 days (around $7 \%$ of the total lead time). A very similar result was also found when considering all thirty contracts as shown in Figure 6.

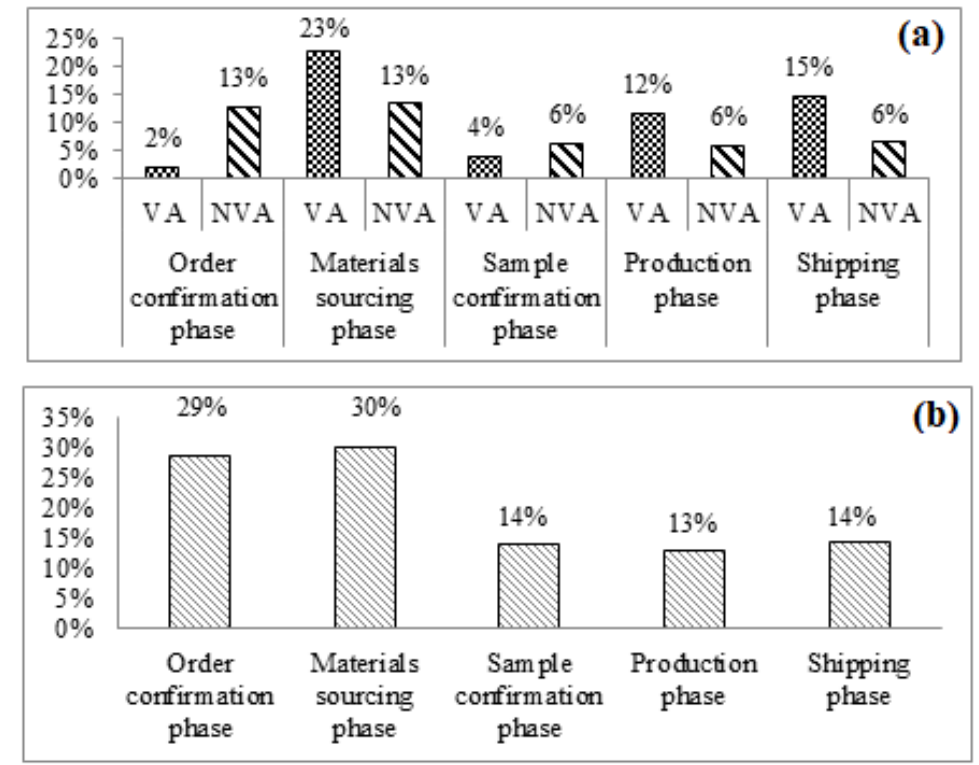

Figure 6. (a) Phase wise value/non-value added activities, (b) $\%$ of non-value against total time

Contract frequencies are higher for the smaller quantity with comparatively shorter lead time i.e. the supply chain under investigation faces the volatile market behavior regarding high product variety and shorter lead time. Additionally, the buyer follows a long forecast period throughout the chain. The longer forecast always increases the risk of forecasting error which may result in high stocks in-store as well as stock out from the market. Higher inventory in the store will decrease the business performance due to an increase in inventory holding cost and a decrease in capital flow. Stockout and late replenishment of products also decrease business performance as a result of losing the market share and valuable customer. A short supply chain is recommended for the apparel industry under investigation as the fashion market is volatile and fashion product lifecycle is short. With shorter lead time, the forecasting period can be shorter which ultimately reduces the risk of forecasting error. Which ultimately increases the buyers' capacity to replenish quickly. 
International Journal of Mathematical, Engineering and Management Sciences

Vol. 5, No. 1, 96-107, 2020

https://doi.org/10.33889/IJMEMS.2020.5.1.009

It is also recommended that the supply chain follow true MTO strategy where the D time (the time a customer is willing to wait) is equal to the $\mathrm{P}$ time (total lead time). In every phase, there are scopes to reduce $\mathrm{P}$ time. By using advanced information technology and long-term relationship with corresponding financial institutes the non-value-added time in order confirmation phase can be eliminated. Again, the commitment and continuous long-term relationship among the supply chain participants may establish a trustworthy business relationship which will also help the chain to minimize the non-value-added time in the order confirmation phase.

The $\mathrm{P}$ time for sample confirmation phase can be shortened with the empowerment of all participants in the supply chain. The participation of all the parties (through organizational learning) within the supply chain in forecasting and product development will reduce forecasting error. Organizational leanings will develop the capability of fabric producers to develop a new fabric during the order confirmation phase before the material sourcing phase as a concurrent activity. In this way, the waiting time (NVA) for the material sourcing phase can be eliminated and the lead time (P time) of this phase can be shortened. Additionally, vendor managed inventory system and empowerment of vendor will help this supply chain to shorten lead time. A modified supply chain as opposed to the current supply chain (Figure 2) by introducing a customer order decoupling point (CODP) to the manufacturer is recommended as shown in Figure 7. As a result, the $\mathrm{P}$ time will become equal to the $\mathrm{D}$ time.

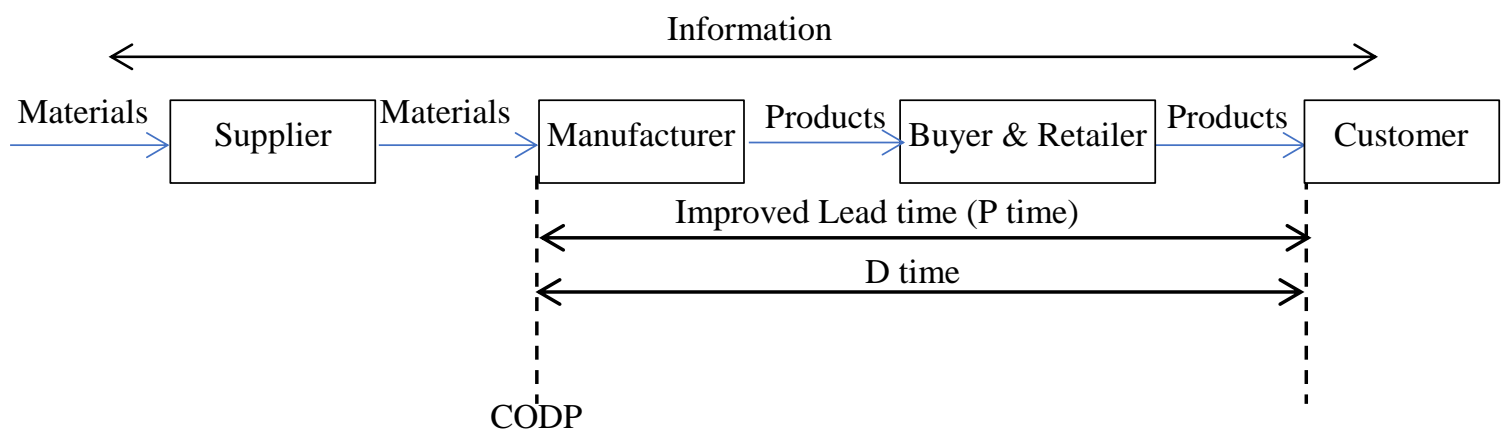

Figure 7. The modified supply chain structure of the current case study with the introduction of CODP

A further improvement of the supply chain can be achieved by introducing scope for quick replenishment of an old style with a new one through a concurrent and parallel production of various styles as shown in Figure 8. In this way, the performance of timeliness-to-market will be increased by fast-to-market and early withdraw a product from the market. When style -1 entered the market earlier it can be withdrawn earlier. A high-profit margin can be achieved as well as the invested capital becomes free earlier. This free capital can be re-inverted for the new style-n. Freeing the capital and gaining the high profit motivates the supply chain participants to develop a new product. In the shipping phase, the non-value-added time can be also minimized with proper planning for transportation schedule, which will reduce waiting time in various stations. 
International Journal of Mathematical, Engineering and Management Sciences

Vol. 5, No. 1, 96-107, 2020

https://doi.org/10.33889/IJMEMS.2020.5.1.009

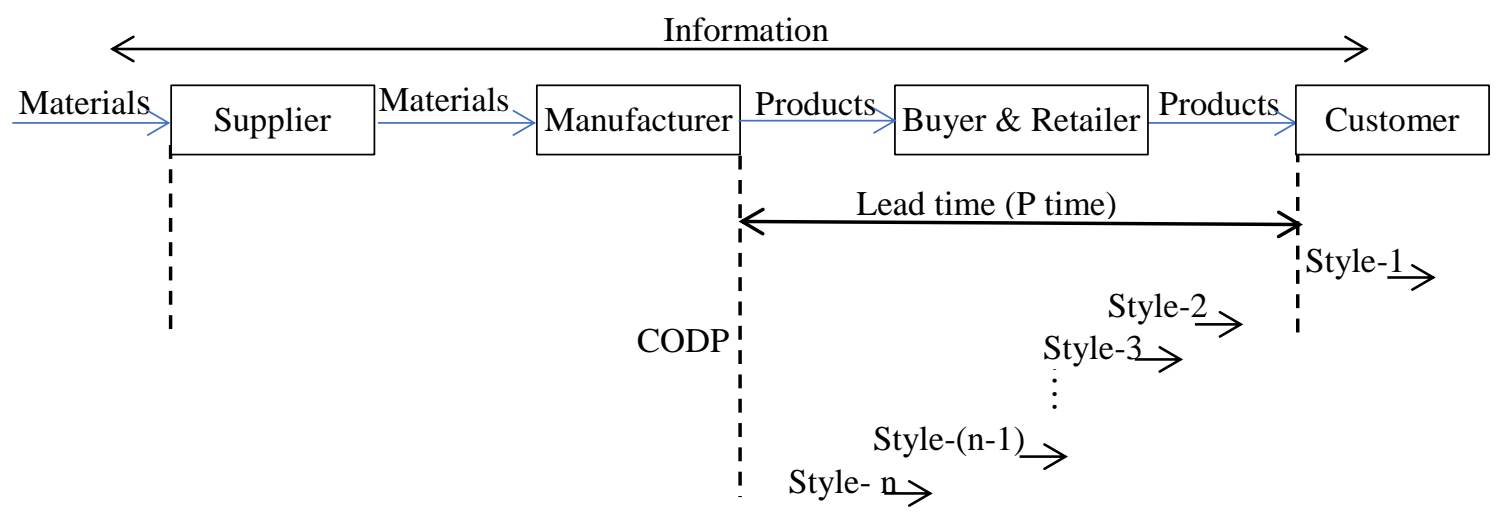

Figure 8. Concurrent and parallel production of various styles

\section{Conclusion}

The apparel supply chain facing tough and global competition for their products even in case of basic items. The competitive issues are price, quality and availability. These three issues are always related to cost and time. Utilization of time along with other resources determines the supply chain performance. The Time-based process mapping is an effective tool to diagnose the process which able the supply chain to take initiatives for better utilization of time. The study reveals that from ordering to retailing there are $44 \%$ to $45 \%$ non-value-added time. The study recommends minimizing this non-value-added time with the introduction of CODP by following an MTO strategy. This MTO strategy can be achieved by the use of advanced information, manufacturing and operational technology in planning, manufacturing, integration and collaboration of different participants of the supply chain. The study also recommends different ways for quick replenishment of the product by a concurrent and parallel production of various styles. The methodology and recommended time compression ways of this study can be applied to other supply chains.

\section{Conflict of Interest}

The authors declare that there is no conflict of interest for this publication.

\section{Acknowledgments}

The authors appreciate the effort from editors and reviewers. This paper did not receive any financial assistance/grants from any funding agencies.

\section{References}

Bhardwaj, V., \& Fairhurst, A. (2010). Fast fashion: response to changes in the fashion industry. The International Review of Retail, Distribution and Consumer Research, 20(1), 165-173.

Bicheno, J., \& Holweg, M. (2000). The lean toolbox (Vol. 4). PICSIE books Buckingham.

Chapman, P. (2003) A tutorial on time based process mapping. In: Supply Chain Knowledge Conference, Cranfield University. UK. 
International Journal of Mathematical, Engineering and Management Sciences

Vol. 5, No. 1, 96-107, 2020

https://doi.org/10.33889/IJMEMS.2020.5.1.009

Christopher, M., \& Towill, D.R. (2002). Developing market specific supply chain strategies. The International Journal of Logistics Management, 13(1), 1-14.

Čiarnienè, R., \& Vienažindienè, M. (2014). Agility and responsiveness managing fashion supply chain. Procedia-Social and Behavioral Sciences, 150, 1012-1019.

Da Silveira, G., Borenstein, D., \& Fogliatto, F.S. (2001). Mass customization: literature review and research directions. International Journal of Production Economics, 72(1), 1-13.

Forza, C., Vinelli, A., \& Filippini, R. (1993, July). Telecommunication services for quick response in the textile-apparel industry. In: Proceedings of the 1st International Symposium on Logistics (pp. 119-26). The University of Nottingham. Nottingham, UK.

Gracanin, D., Buchmeister, B., \& Lalic, B. (2014). Using cost-time profile for value stream optimization. Procedia Engineering, 69, 1225-1231.

Harrison, A., \& Hoek, R.I. (2011). Logistics management \& strategy: competing through the supply chain (Edition 4). Pearson Education Inc. New Jersey.

Kabaivanova, S. (2015). Made to order - the new fashion formula in men's suit market. accessed on 15 May 2019, https://made-to-measure-suits.bgfashion.net/article/10282/61/Made-To-Order-the-new-fashionformula-in-mens-suit-market.

Liu, G., \& Deitz, G.D. (2011). Linking supply chain management with mass customization capability. International Journal of Physical Distribution \& Logistics Management, 41(7), 668-683.

Magnusson, D., \& Simonsson, P. (2012). A framework for decreasing lead times by supplier collaboration. A study performed at Mölnlycke Health Care. Chalmers University of Technology, Sweden.

Martínez, S., Errasti, A., \& Rudberg, M. (2015). Adapting Zara's 'Pronto Moda'to a value brand retailer. Production Planning \& Control, 26(9), 723-737.

McCarthy, I.P. (2004). Special issue editorial: the what, why and how of mass customization. Production Planning \& Control, 15(4), 347-351.

Moin, C.J., Doulah, A.S., Ali, M., \& Sarwar, F. (2018). Implementation of an operating procedure for quality control at production level in a RMG industry and assessment of quality improvement. The Journal of The Textile Institute, 109(4), 524-535.

Moin, C.J., Sarwar, F., \& Doulah, A.S. (2013). Investigation of a hybrid production system for masscustomization apparel manufacturing. Journal of Textile and Apparel, Technology and Management, $8(3), 1-10$.

Pine, B.J., Victor, B., \& Boynton, A.C. (1993). Making mass customization work. Harvard Business Review, 71(5), 108-111.

Qunhui, L., \& Yang, H. (2011). The effects of organizational structure on time-based performance: An empirical study in Chinese automobile industry. Journal on Innovation and Sustainability, 2(3), 59-67.

Simchi-Levi, D., Kaminsky, P., Simchi-Levi, E., \& Shankar, R. (2008). Designing and managing the supply chain: concepts, strategies and case studies. Tata McGraw-Hill Education.

Song, J.-S., \& Zipkin, P. (2003). Supply chain operations: assemble-to-order systems. Handbooks in Operations Research and Management Science, 11, 561-596.

Stalk, G. (1988). Time: the next source of competitive advantage. Harvard Business Review, 66(4), 41-51. 